\title{
A Comparison Between the Application of Brand Functional Value and Brand Experiential Value Toward Consumer Evaluation on Local - Foreign Branding: An Experimental Study
}

\author{
Asysyifa Azzahra1, Tengku Ezni Balqiah" ${ }^{1 *}$ \\ ${ }^{1}$ Faculty of Economics and Business, Universitas Indonesia \\ Email: tebalqiah@yahoo.com
}

\begin{abstract}
Considering the growing number of local products in Indonesia, as well as the increasing number of media types to market the products, it is important for local businessperson and organization to understand the strategy in managing their brands to compete with local and foreign brands. Hence, this study discusses the comparison between the application of brand functional value and brand experiential value toward consumer evaluation in the context of local branding and foreign branding strategy. Consumer evaluation is represented by perceived quality, attitude toward the brand, purchase intention, and word of mouth. The research method used is experimental research with $2 \times 2$ factorial design using fictitious brand as test object. The finding shows that there are differences in value application effect toward consumer evaluation in local and foreign branding context. The combination of foreign branding strategy and experiential value produces the highest perceived quality, attitude toward the brand, and purchase intention, while the combination of foreign branding strategy and functional value yields the highest word of mouth.
\end{abstract}

Type of paper: Empirical

Keywords: Brand; Functional Value; Experiential Value; Local Branding; Foreign Branding; Perceived Quality; Attitude Toward the Brand; Purchase Intention; Word Of Mouth

\section{Introduction}

Indonesia as one of developing countries with approximate population of 250 million people is undoubtedly a very attractive and potential market. Although there has been a slowdown in the world economic growth rate in recent years, the Indonesian's consumption level has been steadily increasing.Based on the data from Central Bureau of Statistics (2016),Indonesia's GDP from year to year is still dominated by consumer spending with a percentage of more than $50 \%$ of total GDP. Interestingly, this growth in consumption level is also accompanied by the growth of small and micro enterprises in Indonesia.From 2013 to 2015, the total growth of micro and small enterprises reached 250,507 unit or $7.33 \%$ (Central Bureau of Statistics, 2015).This 
growth becomes one of the signs of the emergence of local brands in Indonesia.Moreover, this is also supported by the increasing number of platform that can support the marketing process of these products, ranging from increasing awareness, helping information retrieval process, up toselling the products, both online and offline.

Therefore, it becomes more important for Indonesia's local brandsto compete, not only between one another, but also with foreign brands, as the number of foreign brands that enter and traded in Indonesia became one of the things that affect the process of determining the purchase decision. This condition is in line with Hong and Wyer, Jr.'s (1989) opinion where consumer evaluation of a products is often influenced by its knowledge of the country where the product originated or commonly associated with country of origin (COO). Existing research indicates that consumers in developing countries have a stronger preference for non-local brands, especially brands from developed countries where perceived quality and symbolic images related to social status are considered dimensions (Batra et al., 2000; Ergin et al., 2014). Although thefindings seem only benefit brands from certain countries, local brands also have a way to take advantage from this phenomenon by applying foreign branding strategy by branding products with visible or foreign-sounding name (Li and Murray, 1998) that intend to improve the quality of brand image.

Competition between brands is also very dependent on how the brand offers value to consumers. In a brand's value-offering strategy, a prevailing and widespread view is that a brand must focuses on relevant and prominent functional attributes and benefits to achieve successful differentiation (Aaker, 1991; Porter, 1995). However, the rapid development of brands makes consumers overexposed to the functional advantages of existing brands, which, in many product categories, have relatively similar functional advantages (Brakus et al., 2009). Alternatively, the literature on brands then offers an experiential view of the process of brand consumption as a major issue that deserves special consideration (Dalgado-Ballester and Fernandez Sabiote, 2015).

By referring to both strategies that have been outlined as an option to boost local brands competitiveness, this study aims to address the difference between the application of brand functional value and brand experiential value in the context of local brand in Indonesia with local and foreign branding strategy, toward consumer evaluation aspects, especially those aspects that might be exposed when consumers intersecting with new brand, like perceived quality, attitude toward the brand, purchase intention, and word of mouth.

\section{Literature Review}

\subsection{Brand Functional Value vs Brand Experiential Value}

Specifically, brand functional value relates to the ability of a brand to meet consumer's functional needs and wants (Keller, 2001).From this perspective, consumers are viewed as a logical thinker who involved in the reasoning process to purchase the best product out of all alternative products available based on their assessment of functional value (Shafir et al., 1993). Functional value is often called utilitarian value, is defined as an overall assessment of functional benefits and sacrifices, which combine more cognitive aspects, such as "value for money" (Overby and Lee, 2006; Zeithaml, 1988). According to Solomon (2011), consumers 
who focus on utilitarian needs will place emphasis on the tangible purpose and attributes of the products. In the context of advertising, the functional aspect is said to provide a utilitarian reference to the features of a product (e.g. attributes, usage, and product performance) along with the benefits and values resulting from the available features, which will evoke consumer's cognitive response (Abernethy and Franke, 1996).

On the other hand, experiential value contains valuations of experiential gains (e.g. pleasure, freedom, entertainment) that obtained from purchasing or consumption activities. DelgadoBallester and Fernandez-Sabiote (2015) argue that the current trend focuses on the establishment of an exciting brand experience, emphasizing non-functional product characteristics, such as brand related stimuli (e.g. colours, shapes, slogans, backgrounds, design elements, and music) which are part of the brand design, identity, packaging, communication, and environment in which the brand is marketed or sold. Holbrook and Hirschman (1982) argue that brand experiential value refers to subjective aspects, symbolic, hedonic, and psychological, arising from interaction with related brands. These experiential aspects will evoke sensations, feelings, emotions, imaginations, and lifestyles, which will result in an effective response (Brakus et al., 2009; Holbrook and Hirschman, 1982; Schmitt, 1999). Brakus et al. (2009) then classifies these experiential aspects into some categories, such as sensory, affective (e.g. emotions and feelings), intellectual (e.g imagination and creativity), and behavioral (e.g physical experiences and lifestyle).

\subsection{Local Branding vs Foreign Branding}

In relation to the implementation of embedding country of origin into brand name that is seen to affect consumer perception about the quality of a product, there is another strategy that is believed as one important method to influence the brand image, that commonly referred as foreign branding. Although consumers are not familiar with the brand and often find it difficult to pronounce the brand name, their perceptions and attitudes are proven to remain positively affected. For example, in many countries, the words in French can evoke stereotypes of elegance, talent, sensory satisfaction, etc. (Leclerc et al., 1994). In line with this, Li and Murray (1998) state that foreign branding refers to branding a product with a visible or unfamiliar name, while local branding refers to branding a product with a name that matches the characteristics of local language.

\subsection{Hypothesis}

\subsubsection{Brand Functional and Experiential Value Toward Consumer Evaluation}

A brand is alleged to be a sign of quality that plays an important role in the evaluation criteria of a consumers decision-making process (Vraneševic and Stance in Vera, 2015). On the other hand, the perception of quality or commonly known as perceived quality is the consumers' assessment of the advantages found in a product (Zeithaml, 1988). Perceived quality is also defined as the consumers' evaluation of the superiority of a brand as a whole based on intrinsic elements of performance and durability as well as extrinsic elements of brand name (Asshidin et al., 2016). In the cognition-affection model, the researchers acknowledge perceived quality as a cognitive response (Kumar et al., 2009). Thus, it can be said that the functional value that is claimed can provide a utilitarian reference to the features of a product along with the benefits and value generated from the features available and can generate consumer cognitive responses 
(Abernethy \& Franke, 1996), is a more relevant aspect of perceived quality compared with experiential value. Hence:

H1: Perceived quality inbrand functional value is higher thaninbrand experiential value

Brand is the thing that consumers look for, buy, and consume. It means that experiential aspect that occurs between the consumers and the brand is an integral part of the consumer's identification of a particular brand over the other brand (Escalas \& Bettman, Fournier in Zarantonello et al., 2013). This type of interaction, according to Brakus et al., (2009) will present an experience in the form of sensory, affective, intellectual, and behavioral, which will allow consumers to retrieve information and memories that are profitable and relevant to the circumstances of the consumers. In line with this, Sherrington (2003) argues that experiential value provides a rich source of competitive advantage compared to functional value.Thus, brand experiential value is a more relevant antecedent to consumer response to the brand, which in this study is represented by attitude toward the brand because as Spears and Singh (2004) describe, attitude toward the brand is something that relatively immutable, in the form of an unidimensional evaluation summary of a brand that presumably gives energy to produce certain behaviors. Based on the description, then:

$\mathrm{H} 2$ : Attitude toward the brandinbrand experiential value is higher than inbrand functional value

Previous study conducted by Zarantonello et al. (2013) about the rute of functional and experiential persuasion becomes the basis in determining the next hypothesis. Based on the result of the study, in emerging market countries, functional attractiveness has more significant impact on affection and cognition which then becomes the driver in purchase intention, compared with experiential appeal that has no significant impact on affection or cognition, therefore:

H3: Purchase intention in brand functional value is higher than inbrand experiential value

Prior research conducted by Delgado-Ballester and Fernandez-Sabiote (2015) on the comparison of brand functional value and brand experiential value shows that brand functional value has stronger association to word of mouth communication than brand experiential value.Brand functional value becomes a more solutive diagnostic information that determining consumers purchase decision because it relies on more objective variables compared to ambiguous and personalized variables that brand experiential value has. Therefore:

H4: Word of mouth in brand functional value is higher thanin brand experiential value

\subsection{Local Branding and Foreign Branding Toward Consumer Evaluation}

Study conducted by Batra et al. (2000) suggests that consumers in developing countries have a stronger preference for non-local brands, especially brands from developed countries where perceived quality and symbolic images related to social status become a considered dimension. In line with this, the results of study conducted by Ergin et al. (2014) proves that products with foreign brand names or products with foreign branding strategy result in a more positive consumer attitude compared to products with local branding strategy. Overall, the finding suggest that consumers prefer to buy products with foreign brand names for various reasons, such as quality, reliability, functionality, and prestige. Thus, it can be concluded that foreign branding strategy is more relevant to consumer evaluation of the brand. Then:

H5: $\quad$ Perceived quality in foreign branding is higher than in local branding 
H6: Attitude toward the brand in foreign branding is higher than in local branding

H7: $\quad$ Purchase intention in foreign branding is higher than in local branding

H8: Word of mouth in foreign branding is higher than in local branding

\subsubsection{Integration Between Value and Branding Strategy Toward Consumer Evaluation}

Based on the hypothesis in the previous section, the application of brand functional value generatesmore positive perceived quality, purchase intention, and word of mouth, while brand experiential value results in more positive attitude toward the brand. As for branding strategy, foreign branding generates higher perceived quality, attitude toward the brand, purchase intention, and word of mouth. For that, the next hypothesis is a combination of the relationship between value and branding strategy toward consumer evaluation. By combining the application of value and branding strategy as research stimulus, the next hypotheses of this experimental study are:

H9: Perceived quality in the combination of brand functional value and foreign branding is higher than in any other combination

H10: Attitude toward the brand in the combination of brand experiential value and foreign branding is higher than in any other combination

H11: Purchase intention in the combination of brand functional value and foreign branding is higher than in any other combination

H12: Word of mouth in the combination of brand functional value and foreign branding is higher than in any other combination

\section{Research Methodology}

\subsection{Experimental Research Design}

The experimental research design employedin this study is statistical design, specifically $2 \times 2$ factorial design where each cell shows every combination of treatment variables, brand valueand branding strategies.

Table 1. Experimental Research Design

\begin{tabular}{|c|c|c|}
\hline \multirow{2}{*}{ VALUE } & \multicolumn{2}{|c|}{ BRANDING } \\
\cline { 2 - 3 } & Local & Foreign \\
\hline Functional & 1 & 3 \\
\hline Experiential & 2 & 4 \\
\hline
\end{tabular}

As the table above shows, every research participant receives one out of four different types of stimulus which every stimulus is a combination of value and branding strategy, namely: (1) Local branding and brand functional value, (2) Local branding and brand experiential value,(3) Foreign branding and functional value, and (4) Foreign branding and experiential value. Their evaluation then will be measured by four aspects of consumer evaluation: perceived quality, attitude toward the brand, purchase intention, and word of mouth. 
Value and branding strategy as manipulated variables is embedded in four types of stimulus in the form of fictitioushome living brand website display. Every website display is presented in three parts: Home page, about us page, and product page. All elements in the stimulus are formed based on several pilot tests performed prior to the experiment: (1) The first pilot test aims to determine the category of home living products that suitable to be displayed in the stimulus; (2) The second one aims to determine the product type of each selected home living product categories; (3) The purpose of the third pilot test is to choose local and foreign brand name that will serve as local branding and foreign branding strategy. Out of ten choices of local and foreign brand names, Kriya and Craft are selected as a local and foreign branding strategy; (4) The fourth pilot test aims to discover the preference of value presentment for home living products. This will be used as a reference to build the stimulus of brand functional and experiential value in the experiment; (5) The last one is intended to build two types of brand descriptions that emphasize functional and experiential aspects.

In the stimulus, local branding strategy is represented by 'Kriya' as a brand name in Bahasa Indonesia while foreign branding strategy is represented by 'Craft' as a brand name in English. Brand functional value is represented byimages that accentuate quality of a product and descriptions whichhighlighting the quality of materials used, professional product-making process, attention to details, made by skilled and experienced craftsmen, and offer high quality and innovative products. On the other hand, brand experiential value is represented by images that accentuate sensory and feel experiences and descriptions that emphasize passion and love toward design, product-making process that based on creative ideas, crafted by craftsmen who are having high affection to design, and offer products that can create beauty, harmony, and happiness for their owner.

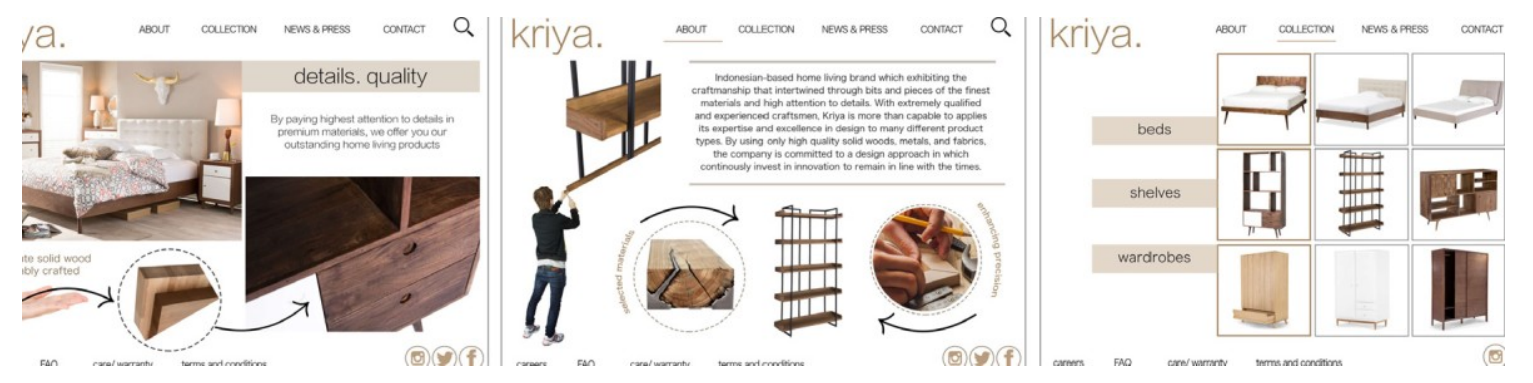

Figure 1. Stimulus of Local Branding and Functional Value

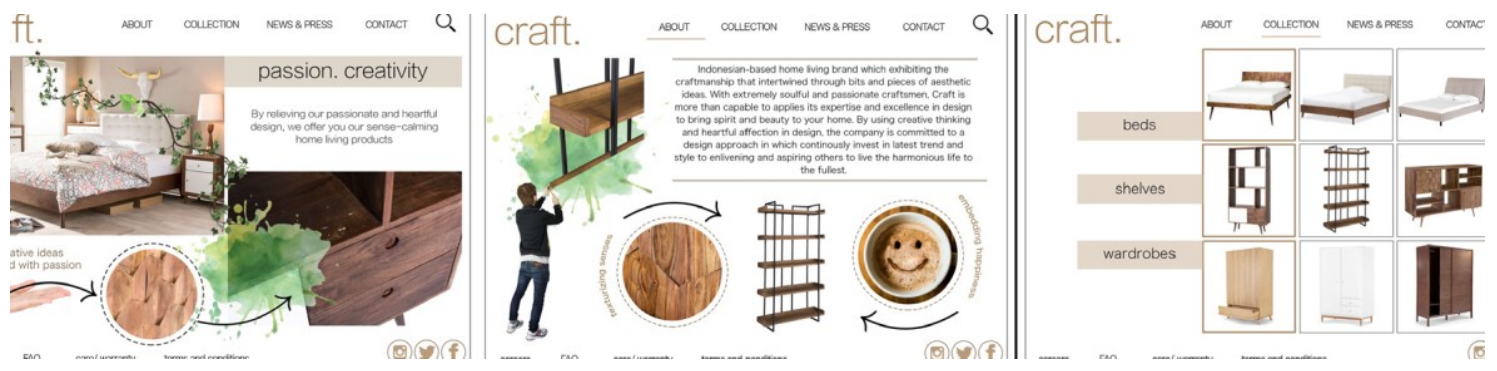

Figure 2. Stimulus of Foreign Branding and Experiential Value 
Table 2. Constructs Summary

\begin{tabular}{|c|c|c|c|}
\hline Variable & Description & Indicator & Source \\
\hline \multirow{3}{*}{$\begin{array}{l}\text { Perceived } \\
\text { Quality }\end{array}$} & \multirow{3}{*}{$\begin{array}{l}\text { Consumer assessment of the } \\
\text { superiority or quality of a product } \\
\text { (Zeithaml, 1988) }\end{array}$} & This brand always represents very good products & \multirow{3}{*}{ Vera (2015) } \\
\hline & & This brand is one of quality & \\
\hline & & The products within this brand are quality products & \\
\hline \multirow{4}{*}{$\begin{array}{l}\text { Attitude } \\
\text { Toward the } \\
\text { Brand }\end{array}$} & \multirow{4}{*}{$\begin{array}{l}\text { An unidimensional evaluation of a } \\
\text { brand that would provide the energy } \\
\text { to produce certain behaviours } \\
\text { (Spears and Singh, 2004) }\end{array}$} & This brand is appealing & \multirow{4}{*}{$\begin{array}{l}\text { Spears and Singh } \\
\quad(2004)\end{array}$} \\
\hline & & This brand is good & \\
\hline & & This brand is pleasant & \\
\hline & & This brand id likable & \\
\hline \multirow{4}{*}{$\begin{array}{l}\text { Purchase } \\
\text { Intention }\end{array}$} & \multirow{4}{*}{$\begin{array}{l}\text { Individual conscious plan to buy a } \\
\text { brand (Spears and Singh, 2004) }\end{array}$} & I definitely buy this brand & \multirow{4}{*}{$\begin{array}{l}\text { Spears and Singh } \\
\quad(2004)\end{array}$} \\
\hline & & I definitely intend to buy this brand & \\
\hline & & I have very high purchase interest & \\
\hline & & I probably buy this brand & \\
\hline \multirow{3}{*}{$\begin{array}{l}\text { Word of } \\
\text { Mouth }\end{array}$} & \multirow{3}{*}{$\begin{array}{l}\text { Communication made by } \\
\text { consumers by marketing the product } \\
\text { directly (Kotler, 2003) }\end{array}$} & I would recommend this brand to my friends & \multirow{3}{*}{$\begin{array}{l}\text { Delgado-Ballester } \\
\text { and Fernandez- } \\
\text { Sabiote }(2015)\end{array}$} \\
\hline & & $\begin{array}{l}\text { I would spread positive word-of-mouth about this } \\
\text { brand }\end{array}$ & \\
\hline & & $\begin{array}{l}\text { If my friend is looking for this kind of product, then I } \\
\text { would tell them to try this brand }\end{array}$ & \\
\hline
\end{tabular}

The experiment and questionnaires were distributed online. After receiving stimulus exposure, every participant went through manipulation check process which will determine whether the data can be used or not. Manipulation check process ensured that participants comprehend the stimulus given.Out of all participants, there were 143 data that passed manipulation check. 44 data for local branding and functional value stimulus, 33 data for local branding and experiential value stimulus, 36 data for foreign branding and functional value stimulus, and 30 data for foreign branding and experiential value stimulus.

\section{$3.4 \quad$ Measures}

All variables were measured through six-point Likert scales ranging from "Strongly disagree" to "Strongly agree". Table 2 summarizes the characteristics of the scales. Perceived quality, which refers to consumer assessment of the superiority or quality of a product(Zeithaml, 1988) is measured using three items adapted from Vera (2015). Attitude toward the brand that reflects an unidimensional evaluation of a brand that would provide the energy to produce certain behaviors (Spears and Singh, 2004)and purchase intention that reflects individual consciousplan to buy a brand (Spears and Singh, 2004) were measured using four items and three items adapted from Spears and Singh (2004), while word of mouth which is conceptualized as communication made by consumers by marketing the product directly(Kotler, 2003) is measured using three items adapted from Delgado-Ballester and Fernandez-Sabiote (2015).

\section{4. $\quad$ Results}

\subsection{Brand Value Application on Local and Foreign Branding Strategy}

Using 0.1 significance levelthat selected because of the bias occurrence possibilities from online-based stimulus exposure and data collection,table 3 indicates that in the context of local branding strategy, the significant difference from functional and experiential value implementation is only found in perceived quality, attitude toward the brand, and purchase intention, while for word of mouth, it 
Table 3. Value Comparison in Local and Foreign Branding Strategy

\begin{tabular}{|c|c|c|c|c|c|}
\hline \multirow[b]{2}{*}{ Variable } & \multirow[b]{2}{*}{ Value } & \multicolumn{2}{|c|}{ LOCAL BRANDING } & \multicolumn{2}{|c|}{ FOREIGN BRANDING } \\
\hline & & Mean & $\begin{array}{c}\text { t-Test } \\
\text { Sig. (1-tailed) }\end{array}$ & Mean & $\begin{array}{c}\text { t-Test } \\
\text { Sig. (1-tailed) }\end{array}$ \\
\hline \multirow{2}{*}{$\begin{array}{c}\text { Perceived } \\
\text { Quality }\end{array}$} & Functional & 4.8714 & \multirow{2}{*}{0.017} & 4.7403 & \multirow{2}{*}{0.084} \\
\hline & Experiential & 4.5652 & & 4.9997 & \\
\hline \multirow{2}{*}{$\begin{array}{l}\text { Attitude } \\
\text { Toward the } \\
\text { Brand }\end{array}$} & Functional & 4.8352 & \multirow{2}{*}{0.059} & 4.7222 & \multirow{2}{*}{0.016} \\
\hline & Experiential & 4.6061 & & 5.1000 & \\
\hline \multirow{2}{*}{$\begin{array}{l}\text { Purchase } \\
\text { Intention }\end{array}$} & Functional & 4.1023 & \multirow{2}{*}{0.095} & 4.0069 & \multirow{2}{*}{0.069} \\
\hline & Experiential & 3.8712 & & 4.3250 & \\
\hline \multirow{2}{*}{ Word of Mouth } & Functional & 4.4184 & \multirow{2}{*}{0.122} & 4.7403 & \multirow{2}{*}{0.097} \\
\hline & Experiential & 4.2324 & & 4.4893 & \\
\hline
\end{tabular}

Table 4. Branding Strategy Comparison in Brand Functional and Experiential Value

\begin{tabular}{|c|c|c|c|c|c|}
\hline \multirow[b]{2}{*}{ Variable } & \multirow[b]{2}{*}{ Branding } & \multicolumn{2}{|c|}{ FUNCTIONAL VALUE } & \multicolumn{2}{|c|}{ EXPERIENTIAL VALUE } \\
\hline & & Mean & $\begin{array}{c}\text { t-Test } \\
\text { Sig. (1-tailed) }\end{array}$ & Mean & $\begin{array}{c}\text { t-Test } \\
\text { Sig. (1-tailed) }\end{array}$ \\
\hline \multirow{2}{*}{$\begin{array}{c}\text { Perceived } \\
\text { Quality }\end{array}$} & Local & 4.8714 & \multirow{2}{*}{0.210} & 4.5652 & \multirow{2}{*}{0.006} \\
\hline & Foreign & 4.7403 & & 4.9997 & \\
\hline \multirow{2}{*}{$\begin{array}{l}\text { Attitude } \\
\text { Toward the } \\
\text { Brand }\end{array}$} & Local & 4.8352 & \multirow{2}{*}{0.240} & 4.6061 & \multirow{2}{*}{0.001} \\
\hline & Foreign & 4.7222 & & 5.1000 & \\
\hline \multirow{2}{*}{$\begin{array}{l}\text { Purchase } \\
\text { Intention }\end{array}$} & Local & 4.1023 & \multirow{2}{*}{0.316} & 3.8712 & \multirow{2}{*}{0.006} \\
\hline & Foreign & 4.0069 & & 4.3250 & \\
\hline \multirow{2}{*}{ Word of Mouth } & Local & 4.4184 & \multirow{2}{*}{0.027} & 4.2324 & \multirow{2}{*}{0.081} \\
\hline & Foreign & 4.7403 & & 4.4893 & \\
\hline
\end{tabular}

confirms that there is no difference in implementing distinct values.It also shows that in local branding context, functional value generates more perceived quality, attitude toward the brand, and purchase intention.

On the other hand, in the context of foreign branding strategy, the significant difference from functional and experiential value implementation is found in all aspects of consumer evaluation. On the contrary to local branding context, it shows that in foreign branding context, experiential value generates more positive consumer evaluation in perceived quality, attitude toward the brand, and purchase intention, however, for the word of mouth communication, functional value is the one who generates more.

\subsection{Branding Strategy on Brand Functional Value and Brand Experiential Value}

In the context of brand functional value implementation, table 4 confirms that the significant difference from local and foreign branding strategy is only found in word of mouth communication, while for the other three aspects, it shows that there are no use in using different branding strategy. Table 4 also shows that foreign branding strategy generates more word of mouth communication. 
Table 5. Comparison in Entire Value and Branding Combination

\begin{tabular}{|c|c|c|c|}
\hline Variable & Stimulus & Mean & Sig. (1-way ANOVA) \\
\hline \multirow{4}{*}{ Perceived Quality } & 1. Local Branding - Functional Value & 4.8714 & \multirow{4}{*}{0.035} \\
\hline & 2. Local Branding - Experiential Value & 4.5652 & \\
\hline & 3. Foreign Branding - Functional Value & 4.7403 & \\
\hline & 4. Foreign Branding - Experiential Value & 4.9997 & \\
\hline \multirow{4}{*}{$\begin{array}{l}\text { Attitude Toward } \\
\text { the Brand }\end{array}$} & 1. Local Branding - Functional Value & 4.8352 & \multirow{4}{*}{0.013} \\
\hline & 2. Local Branding - Experiential Value & 4.6061 & \\
\hline & 3. Foreign Branding - Functional Value & 4.7222 & \\
\hline & 4. Foreign Branding - Experiential Value & 5.1000 & \\
\hline \multirow{4}{*}{ Purchase Intention } & 1. Local Branding - Functional Value & 4.1023 & \multirow{4}{*}{0.078} \\
\hline & 2. Local Branding - Experiential Value & 3.8712 & \\
\hline & 3. Foreign Branding - Functional Value & 4.0069 & \\
\hline & 4. Foreign Branding - Experiential Value & 4.3250 & \\
\hline \multirow{4}{*}{ Word of Mouth } & 1. Local Branding - Functional Value & 4.4184 & \multirow{4}{*}{0.019} \\
\hline & 2. Local Branding - Experiential Value & 4.2324 & \\
\hline & 3. Foreign Branding - Functional Value & 4.7403 & \\
\hline & 4. Foreign Branding - Experiential Value & 4.4893 & \\
\hline
\end{tabular}

Contrart, in the context of brand experiential value, the significant difference from local and foreign branding strategy is seen in all aspects of consumer evaluation, where foreign branding strategy generates more perceived quality, attitude toward the brand, purchase intention, and word of mouth communication.

\subsection{Comparison in Entire Value and Branding Combination}

As for the significance of difference in mean values generated by each combination of stimulus, table 5 indicates that there are significant differences in all aspects of consumer evaluation. In perceived quality, the stimulus of foreign branding and experiential value is proven to produce highest outcome, as well as for attitude toward the brand and purchase intention. On the other hand, the combination of foreign branding and functional value in stimulus 3 generates highest word of mouth communication.

\section{Discussion}

The data analysis results showed that Green Brand Positioning, Green Brand Knowledge, and There is a difference in the outcome of different value implementation in the context of local and foreign branding strategy. In the local branding context, correspond to the hypothesis, functional value generates more perceived quality and purchase intention. This finding confirms that functional value more likely evokes consumer cognitive and affective response that have an impact to consumer's perceived quality and purchase intention. On the contrary, foreign branding context that has more positive quality perception, reliability, and prestige (Ergin et al., 2014) comprises experiential values as the best pair to generates more positive consumer evaluation since they make complete offering. However, functional value still generates more word of mouth because of its solutive and objective qualities.

In the context of functional value implementation, contradict to hypothesis, different branding strategy didn't make any significant difference. It means that for local brand that highlight its functional aspects, it doesn't matter whether their brand name is in Bahasa Indonesia or any other language. This finding also shows the importance of functional descriptions for Indonesia's local 
brands. As for local brands that highlight its experiential elements, it's important to choose foreign language as a brand name. This result suggests that the emphasis of experiential value on local brands should be supported by the circumstances in which the brand already has a positive association, in this case represented by a foreign branding strategy. This positive association is related to the prior research finding that states that foreign branding strategy can influence consumer perception, attitude, and evaluation and perceived value more positively (Karakaya, 2016).

As for comparison of all stimulus, the combination of foreign branding and experiential value is proven to generates more positive consumer evaluation, except word of mouth that sticks with its functional value. This result proves that local brands with foreign branding strategy are considered superior in all aspects of consumer evaluation compared to local brands that embrace local branding strategy. In fact, even value differences can't go beyond the superiority of this strategy.

\section{Conclusion}

Foreign branding strategy has a superior effect in all aspects of consumer evaluation. This strategy, undeniably, has its own appeal to consumers in developing countries like Indonesia because it is associated with higher perceptions of quality, reliability, and prestige (Ergin et al., 2014). That way, it can be said that choosing brand naming strategy by using foreign language can be the best alternative for local business actors. However, it should be noted that the name and meaning of the brand must be tailored to product type and concept. It is also worth noting that based on experiment results, foreign branding and experiential value is the best combination that results highest consumer evaluation. Thus, for local business actors who want to build a new brand, this combination of alternatives can be used as the main alternative. But it does not mean that the description of the offered value should be limited to experiential value only. Of course, functional value must be included, but the portion and emphasis should be more focused on creating experiential value.

Alternatively, business actors who already choose local branding strategy, still have a chance to improve their consumer evaluation, which can be achieved by managing their brand statement especially by giving emphasis on certain value. According to the results of this study, in most aspects of consumer evaluation, the combination of functional value emphasis and local branding strategy can go beyond two other strategy combinations. That means, business players can wrap their local branding strategy with emphasis on functional value in the right way to boost their positive consumer evaluation.

\section{References}

Aaker, D. (1991). Managing Brand Equity: Capitalizing on the Value of a Brand Name. New York: The Free Press.

Abernethy, A. M., \& Franke, G. R. (1996). The Information Content of Advertising: A MetaAnalysis. Journal of Advertising, 25(2), 1-17. 
Asshidin, N. H. N., Abidin, N., \& Borhan, H. B. (2016). Perceived Quality and Emotional Value that Influence Consumer's Purchase Intention towards American and Local Products. Procedia Economics and Finance, 35, 639- 643.

Batra, R., Ramaswamy, V., Alden, D. L., Steenkamp, J. B. E., \& Ramachander, S. (2000). Effects of brand local and nonlocal origin on consumer attitudes in developing countries. Journal of consumer psychology, 9(2), 83-95.

Brakus, J., Schmitt, B., \& Zarantonello, L. (2009). Brand Experience: What Is It? How Is It Measured? Does It Affect Loyalty? Journal of Marketing, 73, 52- 68.

Delgado-Ballester, E., \& Fernandez Sabiote, E. (2015). Brand experimental value versus brand functional value: which matters more for the brand?. European Journal of Marketing, 49(11/12), 1857-1879.

Ergin, E., Akbay, H., \& Ozsacmaci, B. (2014). Insights into Consumer Preference of Foreign Brand Names: Reality or Myth. International Journal of Marketing Studies, 6 (4), $157-$ 164.

Holbrook, M. B., \& Hirschman, E. C. (1982). The Experiential Aspects of Consumption: Consumer Fantasies, Feelings, and Fun. Journal of Consumer Research, 9, 132-140.

Hong, S., \& Wyer, Jr., R. (1989). Effects of country of origin and product attribute information on product evaluation: an information processing perspective. Journal of Consumer Research, 16(2), 175-185.

Karakaya, Ertugrul. (2016). A Comparison of Consumer Attitudes toward Foreign and National Historical Language Used Brand Names: An Investigation in City Of Kirikkale. International Journal of Business and Management Invention, 5(10), 32-39.

Keller, K.L. (2001). Building Customer-Based Brand Equity. Marketing Management, 10(2), 14-19.

Kotler, Philip. (2003). Marketing Management (11th ed.). New Jersey: Prentice Hall Int'1. Kumar, A., Lee, H. J., \& Kim, Y. K. (2009). Indian consumers' purchase intention toward a United States versus local brand. Journal of Business Research, 62(5), 521527.

Leclerc, F., Schmitt, B. H., \& Dube, L. (1994). Foreign Branding and Its Effects on Product Perceptions and Attitudes. Journal of Marketing Research , 31, 263-270.

Li, Z. G., \& Murray, L. W. (1998, January). Should you use foreign branding in China? An exploratory study. In American Marketing Association. Conference Proceedings (Vol. 9, p. 233). American Marketing Association.

Overby, J. W., \& Lee, E. J. (2006). The effects of utilitarian and hedonic online shopping value on consumer preference and intentions. Journal of Business research, 59(10), 1160-1166. 
Porter, M.E. (1995). Competitive Advantage. New York: Free Press.

Schmitt, B. (1999). Experiential Marketing. Journal of Marketing management, 15(1-3), 5367.

Shafir, E., Simonson, I., \& Tversky, A. (1993). Reason-Based Choice. Cognition, 49(1-2), 1136.

Sherrington, M. (2003). Added Value. Palgrave Macmillan.

Solomon, M. (2011). Consumer Behavior: Buying, Having, and Being. New Jersey: Prentice Hall.

Spears, N., \& Singh, S. N. (2004). Measuring attitude toward the brand and purchase intentions. Journal of Current Issues \& Research in Advertising, 26(2), 53-66.

Vera, J. (2015). Perceived brand quality as a way to superior customer perceived value crossing by moderating effects. Journal of Product \& Brand Management, 24(2), 147156.

Zarantonello, L., Jedidi, K., \& Schmitt, B. H. (2013). Functional and experiential routes to persuasion: An analysis of advertising in emerging versus developed markets. International Journal of Research in Marketing, 30(1), 46-56.

Zeithaml, V. A. (1988). Consumer Perceptions of Price, Quality, and Value: A Means-End Model and Synthesis of Evidence. The Journal of Marketing, 2- 22. 